\title{
Branched-chain amino acid-enriched supplementation improves insulin resistance in patients with chronic liver disease
}

\author{
TAKUMI KAWAGUCHI ${ }^{1,2}$, YUMIKO NAGAO ${ }^{1}$, \\ HISAKO MATSUOKA ${ }^{1}$, TATSUYA IDE ${ }^{1,2}$ and MICHIO SATA ${ }^{1,2}$ \\ ${ }^{1}$ Department of Digestive Disease Information and Research; ${ }^{2}$ Division of Gastroenterology, \\ Department of Medicine, Kurume University School of Medicine, Kurume 830-0011, Japan
}

Received February 4, 2008; Accepted March 23, 2008

\begin{abstract}
Increased insulin resistance is a therapeutic target in patients with chronic liver disease. Branched-chain amino acids (BCAA) have been reported to improve insulin resistance in in vivo experiments. Thus, we investigated the effects of BCAA on insulin resistance in patients with chronic liver disease. Twelve patients with chronic liver disease were enrolled. Each patient was given one sachet of a BCAAenriched supplement after breakfast and another at bedtime. The effects of the BCAA-enriched supplementation on insulin resistance were examined 30,60 and 90 days after administration by the homeostasis model assessment method for insulin resistance (HOMA-IR) and for $B$ cell function (HOMA-\%B). The HOMA-IR and HOMA-\%B values were elevated at baseline, however, these parameters showed no significant changes after administration of the BCAA-enriched supplement in the overall patient population. By stratification via gender, patients in the male group showed a significantly greater elevation in the HOMA-IR value compared to the female patients at baseline. After the administration, the HOMA-IR and HOMA-\%B values were significantly decreased only in the male group $(9.4 \pm 4.8$ vs. $2.4 \pm 0.7$, $657 \pm 345$ vs. $126 \pm 36$, respectively; $\mathrm{P}<0.05)$. We found that there was a gender difference in chronic viral liver diseaserelated insulin resistance. Moreover, a BCAA-enriched supplement improved insulin resistance and $B$ cell function in male patients with chronic viral liver disease. Thus, a BCAA-enriched supplement may be a useful therapeutic agent for decreasing insulin resistance in male patients with chronic viral liver disease.
\end{abstract}

Correspondence to: Dr Michio Sata, Department of Medicine and Department of Digestive Disease Information and Research, Kurume University School of Medicine, 67 Asahi-machi, Kurume 830-0011, Japan

E-mail: takumi@med.kurume-u.ac.jp

Key words: hyperinsulinemia, hepatogenous diabetes, valine, leucine, isoleucine, gender difference

\section{Introduction}

The liver is one of the major target organs of insulin and chronic liver disease is associated with insulin resistance (1-3). Increased insulin resistance is related to the progression of hepatic fibrosis (4), development of hepatocellular carcinoma (HCC) $(5,6)$ and reduction in long-term survival $(6,7)$. Thus, the increase in insulin resistance is an important therapeutic target in patients at any stage of chronic liver disease.

Insulin resistance is treated by dietary modification, physical activity and/or drugs (8). However, a sufficient energy intake is required for patients with liver cirrhosis and dietary restrictions may lead to a decrease in liver function $(9,10)$. Although physical activity is not restricted in compensated cirrhotic patients (11), such individuals often complain of fatigue, thus adequate exercise is not always possible. Biguanides and thiazolidinediones are insulin sensitizing agents and are currently utilized for the reduction of insulin resistance $(12,13)$. However, it is not always possible to use these drugs in cirrhotic patients due to adverse effects, including lactic acidosis, fluid retention and severe hepatotoxicity $(14,15)$.

Decreases in serum branched-chain amino acids (BCAA) levels are often seen in patients with chronic liver disease and lead to a decline of detoxified ammonia and albumin production. Therefore, BCAA are used for the treatment of hepatic encephalopathy and hypoalbuminemia $(16,17)$. Previously, BCAA have been reported to modulate insulin signaling in an in vivo study. BCAA cause glucose up-take in the skeletal muscle, adipocytes and hepatocytes in rodents and in a rat model of liver cirrhosis (18-21). In addition, BCAA are known to up-regulate the mammalian target of rapamycin (mTOR), which cross-talks with intracellular insulin signaling $(22,23)$. Taken together, these previous studies imply that BCAA improve glucose metabolism through the reduction of insulin resistance. In this study, we examined the effects of BCAA on insulin resistance in patients with chronic viral liver disease.

\section{Materials and methods}

A prospective, consecutive-patient entry study was conducted. Eligibility criteria were chronic viral liver disease with 
Table I. Contents of one sachet of BCAA-enriched supplement (Aminofeel ${ }^{\circledR}$ ).

\begin{tabular}{lr}
\hline Substance & Amount \\
\hline BCAA & $3200.0 \mathrm{mg}$ \\
Valine & $800.0 \mathrm{mg}$ \\
Leucine & $1600.0 \mathrm{mg}$ \\
Isoleucine & $800.0 \mathrm{mg}$ \\
Calcium & $22.1 \mathrm{mg}$ \\
Magnesium & $12.6 \mathrm{mg}$ \\
Zinc & $5.0 \mathrm{mg}$ \\
Copper & $0.2 \mathrm{mg}$ \\
Selenium & $49.6 \mu \mathrm{g}$ \\
Chromium & $14.4 \mu \mathrm{g}$ \\
Pantothenic acid calcium & $6.8 \mathrm{mg}$ \\
Vitamin A & $315.0 \mu \mathrm{g}$ \\
Vitamin B1 & $2.4 \mathrm{mg}$ \\
Vitamin B2 & $2.6 \mathrm{mg}$ \\
Vitamin B6 & $2.4 \mathrm{mg}$ \\
Vitamin B12 & $10.0 \mu \mathrm{g}$ \\
Folic acid & $0.2 \mathrm{mg}$ \\
Vitamin C & $40.0 \mathrm{mg}$ \\
Vitamin D3 & $3.0 \mu \mathrm{g}$ \\
Vitamin E & $6.4 \mathrm{mg}$ \\
Vitamin K2 & $29.6 \mu \mathrm{g}$ \\
Niacin & $12.0 \mathrm{mg}$ \\
\hline & \\
\hline
\end{tabular}

sufficient food intake and serum albumin concentration $>3.5 \mathrm{~g} / \mathrm{dl}$ and $<4.0 \mathrm{~g} / \mathrm{dl}$. Patients with hepatic encephalopathy, ascites, HCC or renal failure were excluded. A total of 12 patients with $\mathrm{HCV}$-related chronic liver disease $(\mathrm{n}=11)$, or HBV-related chronic liver disease $(n=1)$ were enrolled in this study from August 2006 to June 2007 at Kurume University Hospital. The diagnosis of liver disease was based on clinical, serological, imaging and/or histological evidence. The patients were treated as outpatients and no therapeutic interventions such as changes in eating habits and physical activity were made in the patients' life-style after entering the study. Informed consent for participation in the study was obtained from each patient. The study protocol conformed to the ethical guidelines of the 1975 Declaration of Helsinki as reflected in a prior approval by the Ethics Committee of the Kurume University School of Medicine. None of the subjects were institutionalized.

Study design. Each patient was given one sachet of a BCAAenriched supplement (Aminofeel ${ }^{\circledR}$, Seikatsu Bunkasya Co. Inc, Chiba, Japan) after breakfast and another at bedtime. The
Table II. Characteristics of patients.

\begin{tabular}{|c|c|c|}
\hline & Normal range & All patients \\
\hline $\mathrm{n}$ & & 12 \\
\hline Age & $\mathrm{n} / \mathrm{a}$ & $64.3 \pm 2.4$ \\
\hline BMI $\left(\mathrm{kg} / \mathrm{m}^{2}\right)$ & $18.5-25.0$ & $24.3 \pm 0.6$ \\
\hline Fat $\%$ BW (\%) & $20-27$ & $32.8 \pm 2.4$ \\
\hline Muscle\%BW (\%) & $40-50$ & $36.0 \pm 1.6$ \\
\hline Visceral fat area $\left(\mathrm{cm}^{2}\right)$ & $<100$ & $118.2 \pm 14.9$ \\
\hline Hemoglobin (g/dl) & $14.0-18.0$ & $13.6 \pm 0.4$ \\
\hline White blood cell $(\mu 1)$ & $4000-9000$ & $4358 \pm 414$ \\
\hline Platelet count $\left(\mathrm{x} 10^{4} / \mu 1\right)$ & $13-36$ & $15.3 \pm 1.6$ \\
\hline AST (U/l) & $12-33$ & $43.1 \pm 5.6$ \\
\hline $\operatorname{ALT}(\mathrm{U} / \mathrm{l})$ & $8-42$ & $39.8 \pm 7.3$ \\
\hline LDH (U/1) & $119-229$ & $190.8 \pm 13.0$ \\
\hline$\gamma$-GTP $(\mathrm{U} / \mathrm{l})$ & $10-47$ & $49.7 \pm 8.3$ \\
\hline Total protein $(\mathrm{g} / \mathrm{dl})$ & $6.7-8.3$ & $7.7 \pm 0.2$ \\
\hline Albumin $(\mathrm{g} / \mathrm{dl})$ & $4.0-5.0$ & $3.8 \pm 0.1$ \\
\hline BTR & $4.4-10.1$ & $5.1 \pm 0.4$ \\
\hline BCAAs $(\mu \mathrm{mol} / \mathrm{l})$ & $344-713$ & $435.6 \pm 27.5$ \\
\hline Tyrosine $(\mu \mathrm{mol} / \mathrm{l})$ & $51-98$ & $90.1 \pm 7.9$ \\
\hline Cholinesterase (U/l) & $214-466$ & $155.8 \pm 16.1$ \\
\hline Total bilirubin (mg/dl) & $0.3-1.5$ & $0.9 \pm 0.1$ \\
\hline Total cholesterol (mg/dl) & $128.0-220.0$ & $178.5 \pm 9.1$ \\
\hline Fasting glucose (mg/dl) & $80.0-109.0$ & $104.5 \pm 6.4$ \\
\hline HbA1c $(\%)$ & $4.3-5.8$ & $5.5 \pm 0.2$ \\
\hline IRI $(\mu \mathrm{U} / \mathrm{ml})$ & $5.0-20.0$ & $22.8 \pm 9.7$ \\
\hline HOMA-IR & $<5.4$ & $5.5 \pm 2.1$ \\
\hline HOMA-\%B & $>156.5$ & $326.4 \pm 159.1$ \\
\hline Zinc $(\mu \mathrm{g} / \mathrm{dl})$ & $80-130$ & $82.9 \pm 6.1$ \\
\hline
\end{tabular}

The values are expressed as mean \pm standard error. BMI, body mass index; BW, body weight; AST, aspartate aminotransferase; ALT, alanine aminotransferase; LDH, lactate dehydrogenase; $\gamma$-GTP, $\gamma$-glutamyl transpeptidase; BTR, BCAAs tyrosine ratio; BCAAs, branched-chain amino acids; HbA1c, hemoglobinA1c; IRI, immunoreactive insulin; HOMA-IR, homeostasis model assessment method for insulin resistance; HOMA-\%B, homeostasis model assessment method for $\beta$ cell function; $\mathrm{n} / \mathrm{a}$, not applicable.

contents of this supplement are summarized in Table I. Using blood biochemical tests, effects on liver function including glucose metabolism, derived from the administration of the BCAA-enriched supplement were examined at 30,60 and 90 days.

Measurements of body composition and visceral fat area. Body fat and skeletal muscle were evaluated by an eight-polar direct segmental multifrequency-bioelectrical impedance analyzer (DSM-BIA; InBody 3.2, Biospace, Tokyo, Japan) before and after 90 days of administration of the BCAAenriched supplement and were expressed as fat\%body weight (fat $\% \mathrm{BW}$ ) and muscle\%body weight (muscle\%BW), respectively. Visceral fat area was measured by a DSM-BIA 
Table III. Effects of BCAA-enriched supplementation on body composition, protein, lipid and glucose metabolism.

\begin{tabular}{|c|c|c|c|c|}
\hline & \multirow[b]{2}{*}{ Before } & \multicolumn{3}{|c|}{ Administration of BCAA-enriched supplement } \\
\hline & & 30 days & 60 days & 90 days \\
\hline BMI & $24.3 \pm 0.6$ & $\mathrm{n} / \mathrm{a}$ & $\mathrm{n} / \mathrm{a}$ & $24.2 \pm 0.8$ \\
\hline Fat $\%$ BW & $32.8 \pm 2.4$ & $\mathrm{n} / \mathrm{a}$ & $\mathrm{n} / \mathrm{a}$ & $32.6 \pm 2.4$ \\
\hline Muscle\%BW & $36.0 \pm 1.6$ & $\mathrm{n} / \mathrm{a}$ & $\mathrm{n} / \mathrm{a}$ & $36.1 \pm 1.6$ \\
\hline Visceral fat area & $118.2 \pm 14.9$ & $\mathrm{n} / \mathrm{a}$ & $\mathrm{n} / \mathrm{a}$ & $110.9 \pm 6.2$ \\
\hline BCAAs $(\mu \mathrm{mol} / \mathrm{l})$ & $435.6 \pm 27.5$ & $512.5 \pm 45.3$ & $506.6 \pm 24.3$ & $527.3 \pm 47.1$ \\
\hline Tyrosine $(\mu \mathrm{mol} / \mathrm{l})$ & $90.1 \pm 7.9$ & $84.2 \pm 7.0$ & $77.0 \pm 7.0^{\mathrm{a}}$ & $89.1 \pm 7.1$ \\
\hline BTR & $5.1 \pm 0.4$ & $6.6 \pm 0.8^{\mathrm{a}}$ & $7.2 \pm 0.9^{\mathrm{b}}$ & $6.4 \pm 0.7$ \\
\hline Zinc $(\mu \mathrm{g} / \mathrm{dl})$ & $82.9 \pm 6.1$ & $108.3 \pm 6.9^{a}$ & $106.8 \pm 5.6^{\mathrm{a}}$ & $103.3 \pm 6.9^{\mathrm{a}}$ \\
\hline ALT (U/l) & $39.8 \pm 7.3$ & $43.8 \pm 7.0$ & $42.5 \pm 7.5$ & $42.1 \pm 6.1$ \\
\hline Total protein $(\mathrm{g} / \mathrm{dl})$ & $7.8 \pm 0.2$ & $7.7 \pm 0.2$ & $7.6 \pm 0.1$ & $7.6 \pm 0.2$ \\
\hline Albumin (g/dl) & $3.8 \pm 0.1$ & $3.9 \pm 0.1$ & $3.9 \pm 0.1^{\mathrm{a}}$ & $3.9 \pm 0.1$ \\
\hline Cholinesterase (U/l) & $155.8 \pm 16.1$ & $154.1 \pm 13.8$ & $170.7 \pm 18.3$ & $170.1 \pm 18.5$ \\
\hline Fasting glucose (mg/dl) & $104.5 \pm 6.4$ & $103.9 \pm 6.1$ & $101.8 \pm 5.3$ & $102.8 \pm 5.4$ \\
\hline HbA1c $(\%)$ & $5.5 \pm 0.2$ & $5.5 \pm 0.2$ & $5.5 \pm 0.2$ & $5.4 \pm 0.3$ \\
\hline $\mathrm{IRI}(\mu \mathrm{U} / \mathrm{ml})$ & $22.8 \pm 9.7$ & $12.7 \pm 1.4$ & $10.8 \pm 1.5$ & $13.3 \pm 1.9$ \\
\hline HOMA-IR & $5.5 \pm 2.1$ & $3.3 \pm 0.4$ & $2.8 \pm 0.5$ & $3.5 \pm 0.6$ \\
\hline НОМА-\%В & $326.4 \pm 6.4$ & $127.5 \pm 17.6$ & $112.0 \pm 16.8$ & $140.8 \pm 28.8$ \\
\hline Total cholesterol (mg/dl) & $178.5 \pm 9.1$ & $172.8 \pm 9.4$ & $178.6 \pm 10.0$ & $173.1 \pm 7.2$ \\
\hline Total bilirubin (mg/dl) & $0.9 \pm 0.1$ & $1.0 \pm 0.1$ & $0.9 \pm 0.1$ & $0.9 \pm 0.1$ \\
\hline
\end{tabular}

The values are expressed as mean \pm standard error. Statistical comparisons between before and after 30, 60 or 90 days of the administration were performed by Wilcoxon's test. ${ }^{\mathrm{a}} \mathrm{P}<0.05$ and ${ }^{\mathrm{b}} \mathrm{P}<0.01$. BMI, body mass index; $\mathrm{BW}$, body weight; BCAAs, branched-chain amino acids; BTR, BCAAs tyrosine ratio; ALT, alanine aminotransferase; HbA1c, hemoglobinA1c; IRI, immunoreactive insulin; HOMA-IR, homeostasis model assessment method for insulin resistance; HOMA-\%B, homeostasis model assessment method for $\beta$ cell function; n/a, not applicable.

before and after 90 days of administration of the BCAAenriched supplement. The accuracy of the DSM-BIA analyzer has been reported (24).

Laboratory determinations. Venous blood samples were obtained in the morning after an overnight fast. Complete blood cell counts and levels of serum aspartate aminotransferase, alanine aminotransferase, lactate dehydrogenase, $\gamma$-glutamyl transpeptidase, total protein, albumin, BCAA, tyrosine, cholinesterase, total bilirubin, total cholesterol, immunoreactive insulin (IRI), zinc, plasma glucose and HbA1c were measured by standard clinical methods (Department of Clinical Laboratory, Kurume University Hospital) as previously described $(25,26)$. BCAA tyrosine ratio (BTR) was calculated as BCAA/tyrosine.

Evaluation for insulin resistance and $\beta$ cell function. Insulin resistance and $\beta$ cell function were evaluated on the basis of fasting levels of plasma glucose and insulin, according to the homeostasis model assessment (HOMA) method (27). The formulas used for the HOMA model are as follows: Insulin resistance $(\mathrm{HOMA}-\mathrm{IR})=$ fasting glucose $(\mathrm{mg} / \mathrm{dl}) \times$ fasting insulin $(\mu \mathrm{U} / \mathrm{ml}) / 405 ; \beta$ cell function $($ HOMA-\%B $)=$ fasting insulin $(\mu \mathrm{U} / \mathrm{ml}) \times 360 /[$ fasting glucose (mg/dl) - 63].
Statistical analysis. All data are expressed as mean \pm standard error. Differences between the two groups were analyzed using the Mann-Whitney $U$ test. Statistical comparisons between before administration of the BCAA-enriched supplement and after 30,60, or 90 days, were performed by Wilcoxon's test. P-values $<0.05$ were considered significant.

\section{Results}

Patient characteristics. Patient characteristics prior to BCAA-enriched supplementation administration are summarized in Table II. Serum aspartate aminotransferase and $\gamma$-glutamyl transpeptidase levels were elevated in comparison to normal limits. Serum albumin and cholinesterase levels were decreased. Although the BMI value and the levels of fasting plasma glucose and $\mathrm{HbA1c}$ were within normal limits, the values of fat $\% \mathrm{BW}$, visceral fat area, serum IRI, HOMA-IR, and HOMA- $\%$ B were elevated.

Effects of BCAA-enriched supplement on body composition, protein, lipid and glucose metabolism. The effects on body composition, protein, lipid and glucose metabolism as a result of administering the BCAA-enriched supplementation are summarized in Table III. There were no significant changes on body composition between before and after 90 days 
Table IV. Characteristics of male and female groups.

\begin{tabular}{|c|c|c|c|c|}
\hline & Normal range & Male group & Female group & $\mathrm{P}$ \\
\hline $\mathrm{n}$ & & 5 & 7 & \\
\hline Age & $\mathrm{n} / \mathrm{a}$ & $61.2 \pm 3.4$ & $66.4 \pm 3.3$ & 0.29 \\
\hline BMI $\left(\mathrm{kg} / \mathrm{m}^{2}\right)$ & $18.5-25.0$ & $24.8 \pm 1.1$ & $23.9 \pm 0.8$ & 0.29 \\
\hline Fat $\%$ BW (\%) & $20-27$ & $23.2 \pm 3.0$ & $35.5 \pm 1.6$ & 0.002 \\
\hline Muscle \%BW (\%) & $40-50$ & $42.9 \pm 1.7$ & $34.0 \pm 0.9$ & 0.002 \\
\hline Visceral Fat Area $\left(\mathrm{cm}^{2}\right)$ & $>100$ & $111.0 \pm 12.9$ & $120.3 \pm 18.4$ & 0.66 \\
\hline Hemoglobin (g/dl) & $14.0-18.0$ & $14.4 \pm 0.7$ & $13.0 \pm 0.5$ & 0.17 \\
\hline White blood cell $(/ \mu 1)$ & $4000-9000$ & $4040 \pm 738$ & $4585 \pm 508$ & 0.46 \\
\hline Platelet count $\left(\mathrm{x} 10^{4} / \mu 1\right)$ & $13-36$ & $11.8 \pm 1.5$ & $17.9 \pm 2.0$ & 0.06 \\
\hline AST (U/l) & $12-33$ & $43.6 \pm 6.5$ & $42.7 \pm 8.8$ & 0.46 \\
\hline $\operatorname{ALT}(\mathrm{U} / \mathrm{l})$ & $8-42$ & $51.8 \pm 15.7$ & $31.8 \pm 4.5$ & 0.46 \\
\hline LDH (U/l) & $119-229$ & $177.0 \pm 27.4$ & $205.2 \pm 10.8$ & 0.56 \\
\hline$\gamma$-GTP (U/1) & $10-47$ & $50.6 \pm 8.1$ & $49.0 \pm 13.5$ & 0.68 \\
\hline Total protein $(\mathrm{g} / \mathrm{dl})$ & $6.7-8.3$ & $7.9 \pm 0.3$ & $7.6 \pm 0.2$ & 0.46 \\
\hline Albumin $(\mathrm{g} / \mathrm{dl})$ & $4.0-5.0$ & $3.8 \pm 0.1$ & $3.8 \pm 0.1$ & 0.57 \\
\hline BTR & $4.4-10.1$ & $4.6 \pm 0.6$ & $5.5 \pm 0.5$ & 0.29 \\
\hline BCAAs $(\mu \mathrm{mol} / \mathrm{l})$ & $344-713$ & $509.1 \pm 38.7$ & $383.1 \pm 23.7$ & 0.03 \\
\hline Tyrosine $(\mu \mathrm{mol} / \mathrm{l})$ & $51-98$ & $115.0 \pm 38.7$ & $72.3 \pm 4.8$ & 0.02 \\
\hline Cholinesterase (U/1) & $214-466$ & $171.6 \pm 36.4$ & $144.6 \pm 11.5$ & 0.80 \\
\hline Total bilirubin (mg/dl) & $0.3-1.5$ & $1.0 \pm 0.3$ & $0.8 \pm 0.1$ & 0.80 \\
\hline Total cholesterol (mg/dl) & $128.0-220.0$ & $160.2 \pm 9.9$ & $191.5 \pm 12.0$ & 0.10 \\
\hline Fasting glucose (mg/dl) & $80.0-109.0$ & $105.2 \pm 14.9$ & $104.0 \pm 5.0$ & 0.51 \\
\hline HbA1c $(\%)$ & $4.3-5.8$ & $6.0 \pm 0.4$ & $5.2 \pm 0.1$ & 0.17 \\
\hline $\mathrm{IRI}(\mu \mathrm{U} / \mathrm{ml})$ & $5.0-20.0$ & $40.4 \pm 22.0$ & $10.2 \pm 1.8$ & 0.04 \\
\hline HOMA-IR & $<5.4$ & $9.4 \pm 4.8$ & $2.7 \pm 0.6$ & 0.03 \\
\hline НОМА-\%B & $>156.5$ & $657.6 \pm 345.8$ & $89.8 \pm 14.4$ & 0.17 \\
\hline Zinc $(\mu \mathrm{g} / \mathrm{dl})$ & $80-130$ & $81.8 \pm 10.9$ & $83.7 \pm 7.8$ & 0.46 \\
\hline
\end{tabular}

The values are expressed as mean \pm standard error. Differences between the two groups were analyzed using the Mann-Whitney U test. BMI, body mass index; BW, body weight; AST, aspartate aminotransferase; ALT, alanine aminotransferase; LDH, lactate dehydrogenase; $\gamma$-GTP, $\gamma$-glutamyl transpeptidase; BTR, BCAAs tyrosine ratio; BCAAs, branched-chain amino acids; HbA1c, hemoglobinA1c; IRI, immunoreactive insulin; HOMA-IR, homeostasis model assessment method for insulin resistance; HOMA-\%B, homeostasis model assessment method for $\beta$ cell function; $\mathrm{n} / \mathrm{a}$, not applicable.

of the administration of the BCAA-enriched supplement. Although serum BCAA levels were not significantly increased, the BTR value was significantly increased 30 and 60 days after administration of the BCAA-enriched supplement. The serum zinc level was significantly increased 30, 60 and 90 days after the administration and the serum albumin level was also significantly increased 60 days after the administration. There were no significant changes in fasting plasma glucose, HbA1c, IRI levels, HOMA-IR or HOMA-\%B values after administration of the BCAA-enriched supplement.

Characteristics of the male and female groups. Characteristics of the male and female groups before administration of the BCAA-enriched supplement are summarized in Table IV. Fat $\%$ BW value was significantly higher in the female group than that in the male group. Muscle\%BW value was significantly higher in the male group than that in the female group. Serum BCAAs and tyrosine levels were significantly higher in the male group than those in the female group. Although fasting plasma glucose and HbA1c levels were not significantly different between the two groups, serum IRI level and HOMA-IR values were significantly higher in the male group than those in the female group prior to supplement administration.

Effects of BCAA-enriched supplement on body composition, protein and lipid metabolism in the male and female groups. The effects of administering the BCAA-enriched supplement on body composition, protein and lipid metabolisms in the male and female groups are summarized in Tables V and VI, respectively. There were no significant changes on body composition between before and after 90 days of administration of the BCAA-enriched supplement. 
Table V. Effects of BCAA-enriched supplementation on protein and lipid metabolism in the male group.

\begin{tabular}{|c|c|c|c|c|}
\hline & \multirow[b]{2}{*}{ Before } & \multicolumn{3}{|c|}{ Administration of BCAA-enriched supplement } \\
\hline & & 30 days & 60 days & 90 days \\
\hline BMI & $24.8 \pm 1.1$ & $\mathrm{n} / \mathrm{a}$ & $\mathrm{n} / \mathrm{a}$ & $24.4 \pm 2.1$ \\
\hline Fat $\%$ BW & $23.2 \pm 3.0$ & $\mathrm{n} / \mathrm{a}$ & $\mathrm{n} / \mathrm{a}$ & $23.1 \pm 3.1$ \\
\hline Muscle\%BW & $42.9 \pm 1.7$ & $\mathrm{n} / \mathrm{a}$ & $\mathrm{n} / \mathrm{a}$ & $42.8 \pm 1.9$ \\
\hline Visceral fat area & $111.0 \pm 12.9$ & $\mathrm{n} / \mathrm{a}$ & $\mathrm{n} / \mathrm{a}$ & $109.1 \pm 14.1$ \\
\hline $\mathrm{BCAA}(\mu \mathrm{mol} / \mathrm{l})$ & $509.1 \pm 38.7$ & $569.4 \pm 98.0$ & $488.9 \pm 35.4$ & $437.4 \pm 44.0$ \\
\hline Tyrosine $(\mu \mathrm{mol} / \mathrm{l})$ & $115.0 \pm 10.0$ & $103.7 \pm 6.8$ & $94.2 \pm 11.5^{\mathrm{a}}$ & $102.0 \pm 9.8$ \\
\hline BTR & $4.6 \pm 0.6$ & $5.7 \pm 1.2$ & $5.5 \pm 0.7^{\mathrm{a}}$ & $4.4 \pm 0.5$ \\
\hline Zinc $(\mu \mathrm{g} / \mathrm{dl})$ & $81.8 \pm 10.9$ & $116.0 \pm 15.0^{\mathrm{a}}$ & $97.4 \pm 4.0$ & $87.4 \pm 6.6$ \\
\hline $\operatorname{ALT}(\mathrm{U} / \mathrm{l})$ & $51.8 \pm 15.7$ & $55.6 \pm 14.6$ & $54.0 \pm 16.7$ & $53.2 \pm 13.2$ \\
\hline Total protein $(\mathrm{g} / \mathrm{dl})$ & $7.9 \pm 0.3$ & $7.7 \pm 0.2$ & $7.7 \pm 0.2$ & $7.7 \pm 0.2$ \\
\hline Albumin (g/dl) & $3.8 \pm 0.1$ & $3.9 \pm 0.1$ & $3.9 \pm 0.1$ & $4.0 \pm 0.1^{\mathrm{a}}$ \\
\hline Cholinesterase (U/l) & $171.6 \pm 36.4$ & $166.0 \pm 31.3$ & $201.8 \pm 38.8$ & $203.2 \pm 39.0$ \\
\hline Total cholesterol (mg/dl) & $160.2 \pm 9.9$ & $157.2 \pm 13.9$ & $162.4 \pm 12.7$ & $163.0 \pm 11.8$ \\
\hline Total bilirubin (mg/dl) & $1.0 \pm 0.3$ & $1.2 \pm 0.3$ & $1.0 \pm 0.3$ & $1.1 \pm 0.3$ \\
\hline
\end{tabular}

The values are expressed as mean \pm standard error. Statistical comparisons between before and after 30, 60 or 90 days of the administration were performed by Wilcoxon's test. ${ }^{\mathrm{P}}<0.05$. BMI, body mass index; BW, body weight; BCAAs, branched-chain amino acids; BTR, BCAAs tyrosine ratio; ALT, alanine aminotransferase; n/a, not applicable.

Table VI. Effects of BCAA-enriched supplement on protein and lipid metabolism in the female group.

\begin{tabular}{lcccc}
\hline & & \multicolumn{2}{c}{ Administration of BCAA-enriched supplement } \\
\cline { 4 - 5 } & Before & 30 days & 60 days & 90 days \\
\hline BMI & $23.9 \pm 0.8$ & $\mathrm{n} / \mathrm{a}$ & $\mathrm{n} / \mathrm{a}$ & $24.3 \pm 1.8$ \\
Fat\%BW & $35.5 \pm 1.6$ & $\mathrm{n} / \mathrm{a}$ & $\mathrm{n} / \mathrm{a}$ & $35.3 \pm 1.4$ \\
Muscle\%BW & $34.0 \pm 0.9$ & $\mathrm{n} / \mathrm{a}$ & $\mathrm{n} / \mathrm{a}$ & $34.1 \pm 1.0$ \\
Visceral fat area & $120.3 \pm 18.4$ & $\mathrm{n} / \mathrm{a}$ & $111.4 \pm 4.2$ \\
BCAAs $(\mu$ mol/l) & $383.1 \pm 23.7$ & $471.9 \pm 34.8^{\mathrm{a}}$ & $519.1 \pm 34.6^{\mathrm{a}}$ & $591.6 \pm 66.3^{\mathrm{a}}$ \\
Tyrosine $(\mu \mathrm{mol} / \mathrm{l})$ & $72.3 \pm 4.8$ & $70.3 \pm 7.3$ & $66.2 \pm 6.0$ & $79.9 \pm 8.9$ \\
BTR & $5.5 \pm 5.0$ & $7.3 \pm 1.0$ & $113.6 \pm 8.5$ & $7.7 \pm 9.0$ \\
Zinc $(\mu \mathrm{g} / \mathrm{dl})$ & $83.7 \pm 7.8$ & $34.3 \mathrm{a}$ & $114.6 \pm 8.8^{\mathrm{a}}$ \\
ALT $(\mathrm{U} / \mathrm{l})$ & $31.1 \pm 4.5$ & $35.3 \pm 5.0$ & $7.7 \pm 0.2$ & $34.1 \pm 4.9$ \\
Total protein $(\mathrm{g} / \mathrm{dl})$ & $7.6 \pm 0.2$ & $7.6 \pm 0.2$ & $3.9 \pm 2.4$ & $7.7 \pm 0.2$ \\
Albumin $(\mathrm{g} / \mathrm{dl})$ & $3.8 \pm 0.1$ & $3.9 \pm 4.7$ & $148.4 \pm 11.5$ & $3.9 \pm 0.1$ \\
Cholinesterase $(\mathrm{U} / \mathrm{l})$ & $144.6 \pm 11.5$ & $145.6 \pm 10.1$ & $190.1 \pm 13.5$ & $146.4 \pm 11.3$ \\
Total cholesterol $(\mathrm{mg} / \mathrm{dl})$ & $191.6 \pm 12.0$ & $183.9 \pm 11.5$ & $0.8 \pm 4.2$ & $180.3 \pm 8.7$ \\
Total bilirubin $(\mathrm{mg} / \mathrm{dl})$ & $0.8 \pm 0.1$ & $0.8 \pm 0.1$ & $0.7 \pm 0.1$ \\
\hline
\end{tabular}

The values are expressed as mean \pm standard error. Statistical comparisons between before and after 30, 60 or 90 days of the administration were performed by Wilcoxon's test. ${ }^{\text {P }}<0.05$. BMI, body mass index; BW, body weight; BCAAs, branched-chain amino acids; BTR, BCAAs tyrosine ratio; ALT, alanine aminotransferase; n/a, not applicable.

Significant increases in serum BTR value and zinc level were seen in the two groups after the supplement administration (Tables V and VI). In addition, the serum
BCAA level was significantly increased in the female group (Table VI). The serum albumin level was also significantly increased, though only in the male group (Table V). 
Male
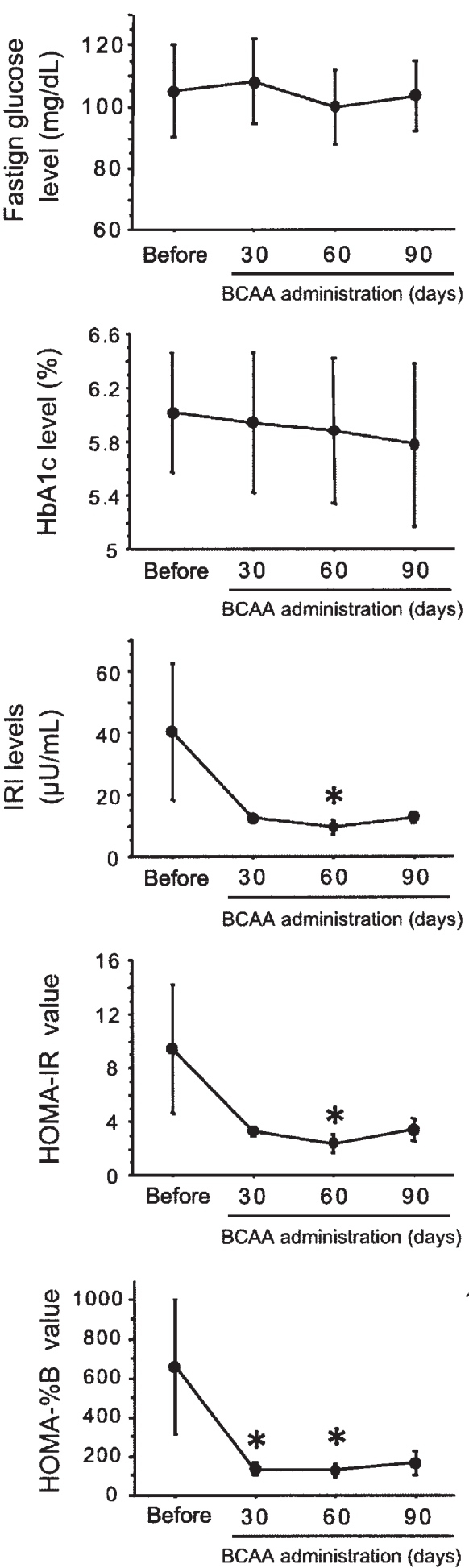

Female


Figure 1. The effects of BCAA-enriched supplementation on glucose metabolism in the male and female groups. Glucose metabolism was evaluated by the fasting glucose level, HbA1c value, serum IRI level, HOMA-IR and HOMA-\%B values. The values are expressed as mean \pm standard error. Statistical comparisons between before and after 30,60 or 90 days of the administration was performed by Wilcoxon's test. *P $<0.05$. HbA1c, hemoglobinA1c; IRI, immunoreactive insulin; HOMA-IR, homeostasis model assessment method for insulin resistance; HOMA-\%B, homeostasis model assessment method for $\beta$ cell function.

Effects of BCAA-enriched supplementation on glucose metabolism in the male and female groups. Although there were no significant changes in the fasting plasma glucose and HbA1c levels during the administration of the BCAAenriched supplement in the two groups, the serum IRI level was significantly decreased in the male group after the supplement administration (Fig. 1). Similarly, a significant decrease was seen in the HOMA-IR and HOMA-\%B values in the male group, though not in the female group (Fig. 1). 


\section{Discussion}

In this study, we demonstrated that there was a gender difference in chronic viral liver disease-related insulin resistance. Moreover, BCAA-enriched supplementation caused decreases in the serum IRI level, the HOMA-IR and HOMA-\%B values without changes in body composition including visceral fat, suggesting the direct effects of the BCAA-enriched supplement on glucose metabolism among the male patients with chronic viral liver disease.

Increased insulin resistance is known to exist in precirrhotic patients (2) and is a risk factor for the progression of hepatic fibrosis $(4)$, development of $\operatorname{HCC}(5,6)$ and a reduction in long-term survival $(6,7)$. Similar to previous reports $(2,6,25,26,28)$, the enrolled patients in this study exhibited chronic hepatitis with increased insulin resistance. Since BCAA are known to modulate insulin signaling (18-21), we examined the effects of the BCAA-enriched supplementation on insulin resistance. In our study, the serum IRI level and the HOMA-IR and HOMA-\%B values were all reduced after the supplement administration. However, the reduction in these parameters was not statistically significant. We previously reported on a gender difference in chronic viral liver disease-related insulin resistance (6). Therefore, we examined the effects of the BCAA-supplement on insulin resistance by stratification via gender.

Male cirrhotic patients show a significantly greater increase in insulin resistance compared to female cirrhotic patients (6). Similarly, increased IRI levels and HOMA-IR values were seen only in the male group in this study. Although the reason for the gender difference in insulin resistance is unclear, one possibility is that tyrosine is involved in the development of insulin resistance. The serum tyrosine level in our study of the male group was significantly increased compared to the female group. A synthetic enzyme of tyrosine, henylalanine hydroxylase, is known to be regulated by testosterone, a sex hormone (29). Tyrosine is the precursor of epinephrine, which causes peripheral and hepatic insulin resistance (30). The serum tyrosine level has a positive correlation with insulin resistance (31). Thus, the gender difference in the tyrosine production pathway and the metabolite of tyrosine may have been responsible for the increased insulin resistance in the male group among our patients.

BCAA-enriched supplementation decreased the serum IRI level and the HOMA-IR and HOMA-\%B values without changes in body composition including visceral fat area. These data suggest that the BCAA-enriched supplementation improves insulin resistance and $B$ cell function. In this study, insulin resistance was significantly reduced 60 days after administration of the BCAA-enriched supplement. It remains unclear, however, how the supplement improved insulin resistance. Since the supplement used in this study contains trace elements such as zinc, chromium and selenium, which are known to decrease insulin sensitivity (32-34), it is reasonable to assume that these trace elements may contribute to improve insulin resistance. Alternatively, changes in the constitution of amino acids may be involved in the improvement in insulin resistance. Moreover, tyrosine is the precursor of epinephrine, which causes peripheral and hepatic insulin resistance (30). In this study, changes in serum tyrosine level and BTR reflected changes in insulin resistance. Insulin resistance was significantly reduced 60 days after the administration of the BCAA-enriched supplement. Likewise, the serum tyrosine level was significantly decreased and BTR was significantly increased 60 days after the administration of the BCAA-enriched supplement. Thus, a decrease in the serum tyrosine level and changes in the constitution of amino acids may contribute to a reduction in insulin resistance. In good agreement with our results, Vlasakova et al reported that BTR shows a negative correlation with insulin resistance (31). Although the reason for changes in the constitution of amino acids remains uncertain, a possibility is that BCAA activate mTOR, which in turn, promotes protein synthesis (35). Desai et al reported that BCAA cause the incorporation of tyrosine into protein as well as albumin renewal (36). In our study, a significant increase in serum albumin level was seen following the decrease in serum tyrosine level and an increase in BTR. Taken together, these findings suggest that the BCAA-enriched supplementation seems to lead to a dramatic reduction of insulin resistance through both changes in the constitution of amino acids and effects of trace elements.

A limitation of this study was the small sample size. However, leucine is reported to improve insulin resistance in in vivo experiments (37). In human subjects, two cases which showed BCAA improved insulin resistance were recently reported (38). These previous reports suggest the effects of the BCAA-enriched supplement on glucose metabolism. In order to confirm the significance of the BCAA-enriched supplement on insulin resistance in patients with LC, a largescale multicenter clinical study is required.

This study revealed that the BCAA-enriched supplementation improved insulin resistance and $B$ cell function in male patients with chronic viral liver disease. Thus, the BCAAenriched supplementation may be one of the useful therapeutic agents for insulin resistance in male patients with chronic viral liver disease.

\section{Acknowledgements}

We thank Noriko Murakami (Seikatsu Bunkasya Co. Inc., Chiba, Japan) and Masaharu Ito (Livence Co. Inc., Tokyo, Japan) for helpful discussions. This study was supported, in part, by a Grant-in-Aid for Young Scientists (B) (No. 19790643 to T.K.) from the Ministry of Education, Culture, Sports, Science and Technology of Japan, the Vehicle Racing Commemorative Foundation, and the Ishibashi Foundation for the Promotion of Science.

\section{References}

1. Megyesi C, Samols E and Marks V: Glucose tolerance and diabetes in chronic liver disease. Lancet 2: 1051-1056, 1967.

2. Kawaguchi T, Yoshida T, Harada M, et al: Hepatitis C virus down-regulates insulin receptor substrates 1 and 2 through upregulation of suppressor of cytokine signaling 3. Am J Pathol 165: 1499-1508, 2004.

3. Kawaguchi T, Takenoshita M, Kabashima T and Uyeda K: Glucose and cAMP regulate the L-type pyruvate kinase gene by phosphorylation/dephosphorylation of the carbohydrate response element binding protein. Proc Natl Acad Sci USA 98: 13710-13715, 2001. 
4. Muzzi A, Leandro G, Rubbia-Brandt L, et al: Insulin resistance is associated with liver fibrosis in non-diabetic chronic hepatitis C patients. J Hepatol 42: 41-46, 2005.

5. Hassan MM, Hwang LY, Hatten CJ, et al: Risk factors for hepatocellular carcinoma: synergism of alcohol with viral hepatitis and diabetes mellitus. Hepatology 36: 1206-1213, 2002.

6. Sumie S, Kawaguchi T, Komuta M, et al: Significance of glucose intolerance and SHIP2 expression in hepatocellular carcinoma patients with HCV infection. Oncol Rep 18: 545-552, 2007.

7. Bianchi G, Marchesini G, Zoli M, Bugianesi E, Fabbri A and Pisi E: Prognostic significance of diabetes in patients with cirrhosis. Hepatology 20: 119-125, 1994.

8. Knowler WC, Narayan KM, Hanson RL, et al: Preventing noninsulin-dependent diabetes. Diabetes 44: 483-488, 1995.

9. Force ABoDatCGT: Guidelines for the use of parenteral and enteral nutrition in adult and pediatric patients. JPEN J Parenter Enteral Nutr 26: 1SA-138SA, 2002.

10. Plauth M, Cabre E, Riggio O, et al: ESPEN Guidelines on Enteral Nutrition: Liver disease. Clin Nutr 25: 285-294, 2006.

11. Ritland S, Foss NE and Gjone E: Physical activity in liver disease and liver function in sportsmen. Scand J Soc Med Suppl 29: 221-226, 1982.

12. Nolan JJ, Ludvik B, Beerdsen P, Joyce M and Olefsky J: Improvement in glucose tolerance and insulin resistance in obese subjects treated with troglitazone. N Engl J Med 331: 1188-1193, 1994.

13. United Kingdom Prospective Diabetes Study (UKPDS). 13: Relative efficacy of randomly allocated diet, sulphonylurea, insulin, or metformin in patients with newly diagnosed noninsulin dependent diabetes followed for three years. BMJ 310 : 83-88, 1995.

14. Shishido S, Koga H, Harada M, et al: Hydrogen peroxide overproduction in megamitochondria of troglitazone-treated human hepatocytes. Hepatology 37: 136-147, 2003.

15. Bailey CJ and Turner RC: Metformin. N Engl J Med 334: 574-579, 1996.

16. Muto Y, Sato S, Watanabe A, et al: Effects of oral branchedchain amino acid granules on event-free survival in patients with liver cirrhosis. Clin Gastroenterol Hepatol 3: 705-713, 2005.

17. Marchesini G, Zoli M, Dondi C, Bianchi G, Cirulli M and Pisi E: Anticatabolic effect of branched-chain amino acid-enriched solutions in patients with liver cirrhosis. Hepatology 2: 420-425, 1982.

18. Nishitani S, Takehana K, Fujitani S and Sonaka I: Branchedchain amino acids improve glucose metabolism in rats with liver cirrhosis. Am J Physiol Gastrointest Liver Physiol 288: G1292-G1300, 2005.

19. Hinault C, Mothe-Satney I, Gautier N, Lawrence JC Jr and Van Obberghen E: Amino acids and leucine allow insulin activation of the $\mathrm{PKB} / \mathrm{mTOR}$ pathway in normal adipocytes treated with wortmannin and in adipocytes from $\mathrm{db} / \mathrm{db}$ mice. FASEB J 18: 1894-1896, 2004.

20. Broca C, Breil V, Cruciani-Guglielmacci C, et al: Insulinotropic agent ID-1101 (4-hydroxyisoleucine) activates insulin signaling in rat. Am J Physiol Endocr Metab 287: E463-E471, 2004.

21. Nishitani S, Matsumura T, Fujitani S, Sonaka I, Miura Y and Yagasaki K: Leucine promotes glucose uptake in skeletal muscles of rats. Biochem Biophys Res Commun 299: 693-696, 2002.

22. Kanazawa T, Taneike I, Akaishi R, et al: Amino acids and insulin control autophagic proteolysis through different signaling pathways in relation to mTOR in isolated rat hepatocytes. J Biol Chem 279: 8452-8459, 2004.
23. Kimball SR, Shantz LM, Horetsky RL and Jefferson LS Leucine regulates translation of specific mRNAs in L6 myoblasts through mTOR-mediated changes in availability of eIF4E and phosphorylation of ribosomal protein S6. J Biol Chem 274: 11647-11652, 1999.

24. Medici G, Mussi C, Fantuzzi AL, Malavolti M, Albertazzi A and Bedogni G: Accuracy of eight-polar bioelectrical impedance analysis for the assessment of total and appendicular body composition in peritoneal dialysis patients. Eur J Clin Nutr 59: 932-937, 2005.

25. Kawaguchi $\mathrm{T}$, Ide $\mathrm{T}$, Taniguchi E, et al: Clearance of HCV improves insulin resistance, beta-cell function, and hepatic expression of insulin receptor substrate 1 and 2 . Am J Gastroenterol 102: 570-576, 2007.

26. Kawaguchi T, Nagao Y, Tanaka K, et al: Causal relationship between hepatitis $\mathrm{C}$ virus core and the development of type 2 diabetes mellitus in a hepatitis $\mathrm{C}$ virus hyperendemic area: a pilot study. Int J Mol Med 16: 109-114, 2005.

27. Matthews DR, Hosker JP, Rudenski AS, Naylor BA, Treacher DF and Turner RC: Homeostasis model assessment: insulin resistance and beta-cell function from fasting plasma glucose and insulin concentrations in man. Diabetologia 28: 412-419, 1985.

28. Itou M, Kawaguchi T, Taniguchi E, et al: Altered expression of glucagon-like peptide- 1 and dipeptidyl peptidase IV in patients with HCV-related glucose intolerance. J Gastroenterol Hepatol 23: 244-251, 2008.

29. Dhondt JL, Dautrevaux M, Biserte G and Farriaux JP: Developmental aspect of phenylalanine hydroxylase in the rat hormonal influences. Mech Ageing Dev 10: 219-224, 1979.

30. Deibert DC and DeFronzo RA: Epinephrine-induced insulin resistance in man. J Clin Invest 65: 717-721, 1980.

31. Vlasakova Z, Valek J, Pelikanova T and Ruzickova J: Relation between serum amino acids and insulin sensitivity (results of a clamp study in offspring of hypertensive patients. Vnitr Lek 43: 195-200, 1997.

32. Faure P, Barclay D, Joyeux-Faure M and Halimi S: Comparison of the effects of zinc alone and zinc associated with selenium and vitamin $\mathrm{E}$ on insulin sensitivity and oxidative stress in high-fructose-fed rats. J Trace Elem Med Biol 21: 113-119, 2007.

33. Anderson RA: Chromium in the prevention and control of diabetes. Diabetes Metab 26: 22-27, 2000.

34. Adachi Y, Yoshida J, Kodera Y, et al: Oral administration of a zinc complex improves type 2 diabetes and metabolic syndromes. Biochem Biophys Res Commun 351: 165-170, 2006.

35. Kimball SR and Jefferson LS: Signaling pathways and molecular mechanisms through which branched-chain amino acids mediate translational control of protein synthesis. J Nutr 136: 227S-231S, 2006.

36. Desai SP, Bistrian BR, Moldawer LL and Blackburn GL: Wholebody nitrogen and tyrosine metabolism in surgical patients receiving branched-chain amino acid solutions. Arch Surg 120: 1345-1350, 1985

37. Zhang Y, Guo K, LeBlanc RE, Loh D, Schwartz GJ and Yu YH: Increasing dietary leucine intake reduces diet-induced obesity and improves glucose and cholesterol metabolism in mice via multimechanisms. Diabetes 56: 1647-1654, 2007.

38. Kawaguchi T, Taniguchi E, Itou M, et al: Branched-chain amino acids improve insulin resistance in patients with hepatitis $\mathrm{C}$ virus-related liver disease: report of two cases. Liver Int 27: 1287-1292, 2007. 